УДК : 371.3.004:89 (061.ICC)

Локшина Олена Ігорівна

доктор педагогічних наук, завідувач відділу порівняльної педагогіки

Інститут педагогіки НАПН України, м. Київ, Україна

luve2001@hotmail.com

\title{
ІКТ-ЗОРІЄНТОВАНІСТЬ ЗМІСТУ ШКІЛЬНОЇ ОСВІТИ В КРАЇНАХ ЄВРОПЕЙСЬКОГО СОЮЗУ
}

\begin{abstract}
Анотація. Статтю присвячено ІКТ-зорієнтованості розвитку змісту шкільної освіти після затвердження Європейської довідкової рамки ключових компетентностей для навчання протягом життя у 2006 р. Охарактеризовано освітню політику держав-членів Свропейського Союзу у напрямі трансформацій шкільної освіти на ІКТ-засади; розкрито підходи до упровадження ІКТ до змісту шкільної освіти, які охоплюють використання міжпредметного підходу, інтеграцію ІКТ знань до змісту навчальних предметів, запровадження окремого навчального предмету. Подано приклади реалізації зазначених підходів на рівні початкової і середньої освіти у країнах Свропейського Союзу. Виокремлено проблеми, які постають перед країнами СС у процесі упровадження ІКТ до змісту шкільної освіти.
\end{abstract}

Ключові слова: інформаційно-комунікаційні технології; ключові компетентності; країни Європейського Союзу; зміст шкільної освіти.

\section{1. ВСТУП}

Постановка проблеми. У 2006 р. Свропейський Парламент та Європейська Рада ухвалили Рекомендацію про ключові компетентності для неперервного навчання, якою було запропоновано Європейську довідкову рамку ключових компетентностей для навчання протягом життя (A European Reference Framework of Key Competencies for Lifelong Learning) для упровадження в державах-членах Європейського Союзу (СС) [6]. Проголошуючи завданням шкільної освіти формування у молоді ключових компетентностей на рівні, що $\epsilon$ необхідним для подальшого життя, Брюссель, фактично, започаткував кардинальну перебудову національних систем шкільної освіти на компетентнісні засади.

Цифрова компетентність $€$ однією 3 восьми ключових компетентностей Свропейської довідкової рамки. Цифрова компетентність характеризується, як така, що передбачає впевнене і критичне використання технології інформаційного суспільства для роботи, дозвілля та спілкування. Фундаментом для неї слугують базові навички 3 IKT: використання комп'ютерів для віднаходження інформації, iii оцінювання, збереження, продукування, презентації та обміну нею, а також для спілкування й участі в інтерактивних мережах через Інтернет. Важливим також вбачається критичне i рефлективне ставлення до наявної інформації, а також відповідальне застосування інтерактивних медійних засобів; інтерес до участі у спільнотах і мережах задля досягнення культурних, соціальних та/або професійних цілей [1].

Прийняття Європейської довідкової рамки ключових компетентностей для навчання протягом життя активізувало діяльність країн СС з трансформації змісту шкільної освіти на компетентнісні засади. Йдеться про формування національних стратегій з упровадження компетентнісних ідей до освітніх стандартів, розроблення валідних технологій оцінювання набуття учнями ключових компетентностей, включаючи цифрову, синонімом якої у багатьох країнах виступає ІК-компетентність. Напрацювання країн ЄС у цій царині є цінними для української освіти з огляду на ії 
кардинальні трансформації у напрямі відповідності запитам сучасного інформаційного суспільства.

Проблемі компетентнісного підходу в освіті зарубіжжя і в Україні присвячено дослідження таких українських учених, як Н. М. Бібік, О. В. Овчарук, О. І. Пометун, О.Я. Савченко та ін., які розглядають траєкторії трансформацій вітчизняної і зарубіжної освіти на компетентнісні засади 3 окресленням викликів і здобутків. Питання реалізації ІК-компетентності в зарубіжжі активно обговорюється у педагогічній спільноті О. В. Овчарук, І. Д. Малицькою, Н.В.Сороко та ін.

Метою цією статті є огляд характеру трансформацій змісту шкільної освіти в країнах СС в аспекті упровадження IК-компетентності.

\section{2. РЕЗУЛЬТАТИ ДОСЛІДЖЕННЯ}

У дослідженні Європейської Комісії «Розвиток ключових компетентностей у школах в Свропі: виклики та можливості для політики» (2012), метою якого є огляд динаміки реалізації Європейської довідкової рамки ключових компетентностей для навчання протягом життя в освіті держав-членів, наголошується, що в умовах існування різних підходів до упровадження компетентнісної ідеї країни ЄС одностайні щодо важливості володіння громадянами IKT [7, 9]. Для упровадження IКкомпетентності (на відміну від деяких інших ключових компетентностей) усіма країнами розроблено національні стратегії, які на рівні шкільної освіти передбачають: інтенсифікацію інтеграції ІКТ у навчальний процес, формування в учнів ІКТ навичок, проведення IКТ-підготовки для педагогів, покращання IКТ-інфраструктури у школах [7, с. 15].

Проведений аналіз засвідчує, що існує три підходи до упровадження ІКТ до змісту початкової і середньої освіти в країнах СС. Це - використання міжпредметного підходу, інтеграція ІКТ знань до змісту навчальних предметів, запровадження окремого навчального предмету.

Лише у Сполученому Королівстві (Англія й Уельс) викладається IKT ma технології на рівні початкової школи. Інші країни дотримуються позиції інтеграції технологічних знань до предметів стандарту початкової освіти. Зокрема: у Франції технологічні знання (поряд з елементами знань 3 природознавства, історії та географії) інтегровано до обов'язкового предмета «Відкриваючи світ»"; у Швеції елементи знань 3 технології включено до природознавства, а у Нідерландах - до предмету «Наука».

ІКТ-грамотність розглядається державами-членами як необхідний інструмент для подальшого успішного навчання кожного учня. Зазвичай, країни дотримуються двох різних підходів під ч с включення цього предмета до стандарту початкової освіти. Так, знання й уміння з ІКТ можуть транслюватися учням як у форматі окремого навчального предмета, так і для навчання інших предметів. За даними дослідження «Базові показники щуодо впровадження IКТ в європейські системи освіти» на рівні МСКО 1 превалює саме другий, так званий інтегративний підхід до навчання IКТ [9, с. 15]. Як окремий предмет IКТ викладається наразі лише у Болгарії, Нідерландах, Румунії, Сполученому Королівстві (крім Північної Ірландії) та Угорщині [9, с. 15]. В інших країнах, зазначає вітчизняний компаративіст О. Овчарук, ІКТ використовується як засіб навчання, передусім базових умінь читання, письма та лічби [2].

Навчання ІКТ на рівні МСКО 1 передбачає набуття учнями обмеженого переліку технічних умінь і навичок, як то вихід в Інтернет, користування електронною поштою, робота з пошуковими системами, підготовка презентації в Power Point тощо. I лише у Національному курикулумі Сполученого Королівства (крім Шотландії) проголошено мету формування в учнів ІКТ-здатності, яка фактично уособлює собою цифрову 
компетентність, означену в Свропейській довідковій рамщі ключових компетентностей для навчання протягом життя - «ІКТ-здатність передбачає володіння учнем технічними та когнітивними вміннями віднаходити, використовувати, створювати та поширювати інформацію, застосовуючи для цього ІКТ-засоби... ІКТ-здатність є значно ширшою, аніж набір технічних компетентностей у застосуванні ІКТ засобів, хоча це $\epsilon$ дуже важливим. Фактично учні мають знати, які IKT $\epsilon$ в наявності, коли їх застосовувати і чому та чи інша ІКТ підходить для виконання певного завдання» $[4,7]$.

Особливістю моделі змісту базової освіти в країнах ЄС є включення предмета 3 основ IКТ до ядра стандарту. Надзвичайна увага до навчання молоді IКТ пов'язана 3 розбудовою в ЄС інформаційного суспільства, у якому володіння ІКТ розглядається вирішальним для успішного навчання і розвитку особистості.

Дослідження, що було проведене в рамках СС з метою виявлення впливу IКТ на шкільну освіту, отримало важливі результати. Було встановлено, що:

- застосування учнями ІКТ у віці 7-16-ти років значно підвищує навчальні досягнення. Зокрема британські учні, які активно використовували IКT, продемонстрували вищі результати на національному тестуванні 3 природознавства на КЕ 3 (вік - 14 років) та під час складання тестів для отримання Свідоцтва про загальну середню освіту (вік - 16 років) порівняно 3 їхніми однолітками;

- за рік після встановлення у школах інтерактивних класних дошок учні значно покращили досягнення під час тестування 3 письма, математики та природознавства порівняно з учнями шкіл, у яких такі дошки були відсутні;

- чим довший час учні користуються комп'ютерами, тим кращі результати демонструють у міжнародних порівняльних дослідженнях, передусім PISA;

- використання IКТ має надзвичайно сильний мотиваційний ефект - покращується ставлення учнів до процесу навчання;

- навчання 3 використанням IКТ підвищує відповідальність учнів за власне навчання, формує навички роботи в групах;

- ІКТ надає змогу вчителям забезпечувати особистісний підхід до навчання i мінімізує соціальний розрив шляхом створення для учнів рівних можливостей в отриманні інформації [3, с. 25-32].

Усвідомлюючи важливість ІКТ вмінь для сучасного життя, держави-члени інтенсифікують дії з навчання їх учнів. По-перше, в останне десятиліття більшість країн ЄC, крім Австрії, Бельгії (франкомовна спільнота), Данії, Ірландії, Північної Ірландії (Сполучене Королівство), Португалії та Швеції, запровадили ІКТ як окремий предмет на рівні МСКО 2 [8, с. 17].

Попри це, очевидним нині для країн $є$ те, що декілька годин на тиждень, які відводяться на викладання цього предмета у школі, не зможуть виконати завдання формування цифрової компетентності, що проголошена Спільнотою життєво необхідною для громадян XXI ст. 3 огляду на це все, більшої ваги набуває інтегральний підхід, який передбачає формування у навчальному закладі так званого IКТ середовища, яке включає обов'язковий для всіх учнів навчальний предмет, застосування IКТ знань і вмінь у навчанні інших предметів, ІКТ грамотність педагогів, посаду IКТ координатора, IКТ інфраструктуру, що складається з апаратного (hardware) i програмного (software) забезпечення і підключення до Інтернету.

Як свідчить дослідження «Базові показники впровадження IKT в європейські освітні системи. Факти $і$ ичирри» (Basic Indicators on the Incorporation of ICT into European Education Systems. Facts and Figures), що проводилося в рамках EURYDICE, зміст ІКТ спрямовано на виконання таких чотирьох основних завдань: 
- навчити правильно використовувати Word, Excel, Power Point, інші комп'ютерні програми;

- навчити відшукувати інформацію на електронних носіях і в мережах;

- навчити спілкуватись у мережі;

- сформувати навички програмування [8, с. 22].

Крім перелічених, що є спільними для всіх країн, деякі ставлять додаткові завдання. Так, зміст IKT у Німеччині спрямовано на усвідомлення питань інтелектуальної власності й ролі комп'ютера для кар'єри, а в Іспанії, Нідерландах, Чехії - на цінність і надійність інформації й ролі ІКТ у суспільстві [там само].

Сполучене Королівство розглядається як найбільш просунута країна 3 інформатизації освіти серед країн ЄС. Нині предмет Інформаційно-комунікаційні технології входить до переліку базових у Національному курикулумі (Англія й Уельс) і $\epsilon$ обов'язковим для вивчення учнями на КЕ 3 та КЕ 4 . Його метою $є$ формування у школярів ІКТ-здатності, яка передбачає «аналіз, обмін і презентацію інформації для розв'язання завдань, проведення досліджень та розвиток творчості з метою отримання максимальних переваг шляхом застосування інструментів i технологій, зокрема, апаратного і програмного забезпечення, таких інформаційних джерел, як CD-ROM та Інтернет і споріднених технологій (роботи, відеоконференції, цифрове телебачення)» $[9,1]$.

До моменту запровадження цього предмета у британських школах у звітах Інспекторату з питань освіти Її Величності Королеви (Her Majesty's Inspectorate of Education) наголошувалось на «неглибокій культурі володіння учнями IКТ вмінь», що пов'язувалося 3 використанням учителями лише окремих аспектів IКТ під час викладання предметів Національного курикулуму [3 с. 71].

Нині ІКТ-здатність формується у школярів завдяки практико-зорієнтованості змісту предмету IKT - «знання з ІКТ $є$ набагато більш вміннє- або техніко- аніж знаннєво-базованими», відмічають британські вчені С. Кеннеуел (Steve Kennewell) i Дж. Паркінсон (John Parkinson), аналізуючи Національний курикулум [9, 8].

Крім викладання окремого предмета, Наџіональний курикулум передбачає обов'язкове застосування знань і вмінь з ІКТ під час опанування учнів, змісту інших предметів - англійської мови, математики, історії, географії, мистеитва та дизайну, проектування та технології, сучасних іноземних мов, природознавства, фізичного виховання (табл. 1) [систематизовано автором на основі джерела http://www.ncaction.org.uk/subjects/ict/inother.htm].

Таблиия 1

\section{ІКТ для навчання предметів Національного курикулуму}

\begin{tabular}{|c|l|}
\hline Предмети НК & \multicolumn{1}{|c|}{ ІКТ допомагає учням } \\
\hline Англійська мова & $\begin{array}{l}\text { спілкуватися, редагувати, структурувати, зберігати та } \\
\text { презентувати тексти }\end{array}$ \\
\hline Математика & $\begin{array}{l}\text { обчислювати дані, перевіряти гіпотези, будувати графіки, } \\
\text { малювати геометричні фігури, доводити теореми }\end{array}$ \\
\hline $\begin{array}{c}\text { Природознавство } \\
\text { проводити експерименти і спостереження; обробляти отримані } \\
\text { результати, створюючи таблиці і графіки; прискорювати } \\
\text { процеси, які в живій природі є довготривалими, небезпечними } \\
\text { чи занадто дорогими для дослідження }\end{array}$ \\
\hline $\begin{array}{c}\text { Сучасні іноземні } \\
\text { мови }\end{array}$ & $\begin{array}{l}\text { спілкуватися 3 носіями мови 3 інших країн; мати доступ до } \\
\text { автентичних джерел 3 мови, яка вивчається; розуміти }\end{array}$ \\
\hline
\end{tabular}




\begin{tabular}{|c|c|}
\hline & $\begin{array}{l}\text { граматичні правила; ознайомлюватися } 3 \text { культурою країни, } \\
\text { мова якої вивчається }\end{array}$ \\
\hline Географія & $\begin{array}{l}\text { розвивати навички географічного } \\
\begin{array}{l}\text { мапами, проводити } \\
\text { отратистичний } \\
\text { отримувати доступ до просторовий аналіз, } \\
\text { географічні процеси }\end{array}\end{array}$ \\
\hline Історія & $\begin{array}{l}\text { знайомитися } 3 \text { історичними подіями, отримувати доступ до } \\
\text { першоджерел, обробляти й аналізувати дані }\end{array}$ \\
\hline $\begin{array}{c}\text { Мистецутво та } \\
\text { дизайн }\end{array}$ & $\begin{array}{l}\text { навчатися мистецтву і дизайну, оптимізуючи розвиток } \\
\text { творчості, надаючи більшу автономію в процесі творчості, } \\
\text { особливо в навчанні візуальних концептів, створенню медіа } \\
\text { продуктів, Інтернет-галерей, графіків }\end{array}$ \\
\hline $\begin{array}{c}\text { Проектування та } \\
\text { технологія }\end{array}$ & $\begin{array}{l}\text { займатися проектуванням, } \\
\text { компютерні } \begin{array}{l}\text { прогромистовуючи } \\
\text { моделювання, креслення }\end{array} \text { длеціальні } \\
\text { малювання, } \\
\text { фарбуванн, }\end{array}$ \\
\hline Музика & робити музичні записи, писати та виконувати музику \\
\hline
\end{tabular}

На сучасному етапі формування IКТ-здатності у британських школярів виходить на якісно новий рівень завдяки використанню новітніх віянь в ІКТ галузі. По-перше, це - бездротовий Інтернет (Wi-Fi), який надає можливість постійно працювати у мережі 3 ноутбуками і мобільними телефонами. Іншою інновацією є мультимедія — цифрове телебачення, електронні дошки, веб-сайти, Інтранет, які руйнують кордони під час спілкування, отримання інформації, сприйняття світу.

Проблемним питанням у контексті упровадження IК-компетентності у школах $\epsilon$ оцінювання оволодіння нею школярами. Слід зазначити, що країни $С С$ підходять до цього питання комплексно, оцінюючи володіння учнями ІКТ як опосередковано (у процесі, наприклад, складання іспитів/тестів 3 інших предметів), так і шляхом використання відповідних оцінних інструментів і сертифікаційних траєкторій. Так, у Франції використовують Диплом з інформаційних технологій та Iнтернету (B2i) у молодшій і старшій середніх школах; у Бельгії - необов'язковий ІКТ-паспорт, у Шотландії - ІКТ-сертифікат. На європейському рівні застосовується сертифікат Європейська комп'ютерна лічензія водія (ECDL), визнаний усіма країнами $\mathrm{CC}$ [7, с. 30].

Водночас, країни знаходяться у пошуку ефективних технологій, які б могли комплексно виміряти не лише технологічні, а й ціннісні аспекти. У дослідженні Європейської Комісії «Оцінювання ключових компетентностей» (2012) наводиться, зокрема, досвід Австрії, де відбувається апробація технології портфоліо для оцінювання оволодіння школярами 14-15-річного віку таких надпредметних ключових компетентностей, як уміння вчитись, соціальна і громадянська, підприємницька, культурна та цифрова. Портфоліо використовуються як для проведення розвивального, так i підсумкового оцінювання. Останнє розглядається як дуже важливе для подальшого руху учнів у системі освіти [5, с. 34].

\section{3. ВИСНОВКИ ТА ПЕРСПЕКТИВИ ПОДАЛЬШИХ ДОСЛІДЖЕНЬ}

Аналіз сучасних підходів до упровадження ІКТ до змісту шкільної освіти в країнах ЄС засвідчує, по-перше, їх одностайність щодо важливості володіння громадянами Спільноти ІК-компетентністю. Про це свідчить розроблення й реалізація 
усіма державами-членами національних стратегій імплементації IКТ в освіту. На це потрібно завернути увагу й розробникам освітньої політики в Україні.

В умовах різної динаміки імплементації ІКТ країни віднайшли спільні підходи, які охоплюють використання міжпредметного підходу, інтеграцію IКТ знань до змісту навчальних предметів, запровадження окремого навчального предмету. Спільні напрацювання $\epsilon$ важливими для України, яка підпорядковується загальним європейським тенденціям розвитку, включно з освітою.

Висвітлені у статті аспекти не вичерпують усіх трансформацій, що відбувають в освітній політиці і шкільній практиці країн СС у царині збагачення змісту освіти IКТ ідеями, що відкриває необхідність подальших компаративних розвідок. Особливо важливим залишається аспект оцінювання набуття школярами ІК-компетентності, як i підготовки до цього вчителів.

\title{
СПИСОК ВИКОРИСТАНИХ ДЖЕРЕЛ
}

1. Локшина О. І. Зміст шкільної освіти в країнах Європейського Союзу: теорія і практика (друга половина XX - початок XXI ст.) : монографія / О. І. Локшина. - К. : СПД Богданова А. М., 2009. $404 \mathrm{c}$

2. Овчарук О. В. Місце та роль інформаційних та комунікаційних технологій в системі освіти країн Європейського Союзу [Електронний ресурс] / О. В. Овчарук // Інформаційні технології і засоби навчання. - 2008. - № 2 (6). - Режим доступу до журн.: http://www.nbuv.gov.ua/ejournals/ITZN/em6/emg.html.

3. Balanskat A. The ICT Impact Report. A Rewiew of Studies on ICT Impact on Schools in Europe. 11 December 2006 / Anja Balanskat, Roger Blamire, Stella Kefala. - Brussels : European Communities, European Schoolnet, 2006. - 69 p.

4. DfES (Department for Education and Skills). Key Stage 3. National Strategy. ICT across the Curriculum. ICT in Art and Design. - London : Crown, 2004. - 40 p.

5. European Commission. Education and Training 2020 Work programme. Thematic Working Group “Assessment of Key Competences”. Literature Review, Glossary and examples. - November 2012. Режим доступу : http://ec.europa.eu/education/policy/school/doc/keyreview_en.pdf.

6. European Union. Key Competencies for Lifelong Learning. Recommendation of the European Parliament and to the Council of 18 December 2006 (2006/962/EC) // Official Journal of the European Union. 2006. - 30 December. - P. I. 394/10 - I. 394/18.

7. Eurydice. Developing Key Competence at School in Europe: Challenges and Opportunities. Eurydice Report. - Luxembourg: European Commission, EACEA, Eurydice. - 2012. - 68 p.

8. Eurydice. Basic Indicators on the Incorporation of ICT into European Education Systems. Facts and Figures. 2000/01 Annual Report. - Brussels : European Eurydice Unit, 2001. - 50 p.

9. Kennewell S. Developing the ICT Capable School / Steve Kennewell, John Parkinson, Howard Tanner. Florence : Routledge, 2000. - 199 p.

10. OfSTED (Office for Standards in Education, Children's Services and Skills). ICT in Schools. The Impact of Government Initiatives Five Years On. - London : Ofsted Publications Centre "Crown”, 2004. - 66 p.

Матеріал надійшов до редакиї 25.02.2015 p.

\section{ИКТ-ОРИЕНТИРОВАННОСТЬ СОДЕРЖАНИЯ ШКОЛЬНОГО ОБРАЗОВАНИЯ В СТРАНАХ ЕВРОПЕЙСКОГО СОЮЗА}

\author{
Локшина Елена Игоревна \\ доктор педагогических наук, заведующая отделом сравнительной педагогики \\ Институт педагогики НАПН Украины, г. Киев, Украина \\ luve2001@hotmail.com
}

Аннотация. Статья посвящена ИКТ-ориентированности развития содержания школьного образования в странах Европейского Союза после принятия Европейской справочной рамки ключевых компетентностей для обучения на протяжении жизни в 2006 г. Раскрыто подходы 
стран-членов к внедрению ИКТ в содержание школьного образования; поданы примеры реализации этих подходов на уровне начального и среднего образования; определены проблемы, которые сопровождают страны в процессе внедрения ИКТ идей в содержание школьного образования.

Ключевые слова: информационно-коммуникационные технологии, ключевые компетентности, страны Европейского Союза, содержание школьного образования.

\title{
ICT-ORIENTATION OF THE SCHOOL EDUCATION CURRICULUM IN THE COUNTRIES OF THE EUROPEAN UNION
}

\author{
Olena I. Lokshyna \\ Doctor of Science in Pedagogy, Head of the Comparative Education Department \\ Institute of Pedagogy of the NAES of Ukraine, Kyiv, Ukraine \\ luve2001@hotmail.com
}

\begin{abstract}
The article is devoted to the ICT-orientation of the school education curriculum development in the countries of the European Union after the European Reference Framework of the Key Competences for Lifelong Learning adoption in 2006. The author reveals the approaches of the member states to the ICT implementation into the school curriculum; gives examples of these approaches realization at the primary and secondary school levels; defines the problems which arise during the ICT ideas implementation into the school curriculum.
\end{abstract}

Keywords: information and communication technologies; key competences; the countries of the European Union; school education curriculum.

\section{REFERENCES (TRANSLATED AND TRANSLITERATED)}

1. Lokshyna O. I. The content of school education in the European Union: Theory and Practice (second half of the XX century - beginning of the XXI century.): Monograph / O. I. Lokshyna. - K. : SPD Bogdanova A.M., 2009. $-404 \mathrm{~s}$ (in Ukrainian).

2. Ovcharuk O. V. The place and role of ICT in the education system of the European Union [online] / O. V. Ovcharuk // Informatsiini tehnologii i zasoby navchannya. - 2008. - № 2 (6). - Available from : http://www.nbuv.gov.ua/e-journals/ITZN/em6/emg.html (in Ukrainian).

3. Balanskat A. The ICT Impact Report. A Rewiew of Studies on ICT Impact on Schools in Europe. 11 December 2006 / Anja Balanskat, Roger Blamire, Stella Kefala. - Brussels : European Communities, European Schoolnet, 2006. - 69 p. (in English).

4. DfES (Department for Education and Skills). Key Stage 3. National Strategy. ICT across the Curriculum. ICT in Art and Design. - London : Crown, 2004. - 40 p. (in English).

5. European Commission. Education and Training 2020 Work programme. Thematic Working Group "Assessment of Key Competences". Literature Review, Glossary and examples [online]. - November 2012. - Available from : http://ec.europa.eu/education/policy/school/doc/keyreview_en.pdf (in English).

6. European Union. Key Competencies for Lifelong Learning. Recommendation of the European Parliament and to the Council of 18 December 2006 (2006/962/EC) // Official Journal of the European Union. 2006. - 30 December. - P. I. 394/10 - I. 394/18. (in English).

7. Eurydice. Developing Key Competence at School in Europe: Challenges and Opportunities. Eurydice Report. - Luxembourg : European Commission, EACEA, Eurydice, 2012. - 68 p. (in English)

8. Eurydice. Basic Indicators on the Incorporation of ICT into European Education Systems. Facts and Figures. 2000/01 Annual Report. - Brussels : European Eurydice Unit, 2001. - 50 p. (in English).

9. Kennewell S. Developing the ICT Capable School / Steve Kennewell, John Parkinson, Howard Tanner. Florence : Routledge, 2000. - 199 p. (in English).

10. OfSTED (Office for Standards in Education, Children's Services and Skills). ICT in Schools. The Impact of Government Initiatives Five Years On. - London : Ofsted Publications Centre "Crown", 2004. - 66 p. (in English). 